\title{
Physicochemistry, morphology and leachability of selected metals from post-galvanized sewage sludge from screw factory in Łańcut, SE Poland
}

\author{
Dagmara Galas*, Jan Kalembkiewicz, Elżbieta Sitarz-Palczak \\ Rzeszow University of Technology, Faculty of Chemistry, Powstańców Warszawy 6 Ave., 35-959 \\ Rzeszów, Poland \\ Correspondence:dgalas@stud.prz.edu.pl
}

Received: $17^{\text {th }}$ July, 2016

Accepted: $3^{\text {rd }}$ October, 2016

\begin{abstract}
Morphology, physicochemical properties, chemical composition of post-galvanized sewage sludge from Screw Factory in Łańcut, leachability and mobility of metals has been analyzed. The analyses with the use of scanning electron microscope with an adapter to perform chemical analysis of microsites (EDS) showed that the material is characterized by a high fragmentation and a predominant number of irregularly shaped grains. The sewage sludge is alkaline with a large loss of ignition (34.6\%) and small bulk density $\left(<1 \mathrm{~g} / \mathrm{cm}^{3}\right)$. The EDS analyses evidenced presence of oxygen, silicon, calcium, chromium, iron and zinc in all examined areas, and presence of manganese and copper in selected areas indicating a non-uniform distribution of metals in the sewage sludge. Within one-stage mineralization and FAAS technique a predominant share of calcium, zinc and iron in terms of dry matter was recorded in the sewage sludge. The contents of $\mathrm{Co}, \mathrm{Cr}, \mathrm{Cu}, \mathrm{K}, \mathrm{Mn}, \mathrm{Ni}$ and $\mathrm{Pb}$ in sewage sludge are below $1 \%$. Evaluation of mobility and leaching of metals in sewage sludge was carried out by means of two parameters: accumulation coefficient of mobile fractions and leaching level related to the mass solubility of sewage sludge. The results indicate that the short-term or long-term storage of not inactivated post-galvanized sewage sludge can result in release of metals.
\end{abstract}

Key words: post-galvanized sewage sludge, leachability, heavy metals

\section{Introduction}

Industry annually produces a significant amount of waste. Some of the waste is being processed and some is being stored in landfills posing an ever-increasing ecological threat. Industrial waste management in Poland includes recycling, neutralization (storage or incineration), transfer to other recipients and temporary storage (Rosolak and Gworek 2006; Wengierek 2014). In 2015, over 125 million tons of industrial waste was produced in Poland (Central Statistical Office of Poland 2015). Industrial waste pose a threat to natural environment when is produced, transported and stored (Lambolez et al. 1994). Particularly noteworthy are wastes from galvanizing industry. Currently in Poland there are over 600 galvanizing plants engaged in the processes of surface plating (mainly: chromium plating, nickel plating, zinc plating, tin plating, copper plating, silver plating) (Surgiewicz 2006). Sewage from galvanizing plants are characterized by a high content of metal ions (including heavy metals) which are classified as particularly dangerous and harmful to natural environment (Espinosa and Tenório 2001; Bojanowska et al. 2001; Haoxin et al. 2014; Grabas 2009; Ruth 2013; Rubel 2009). Heavy metals are considered, at this stage of development, as redundant or even toxic. Introduced into the body in small doses over a long period of time can cause acute or chronic poisoning, cardiovascular diseases, 
neurological disorders, excretory system disorders and even cancer (Duffus, 2002; Duruibe, 2007). Nowadays, analyses of morphology, physicochemical properties and chemical composition of waste from galvanizing industry are an important aspect of anthropogenic environmental pollution monitoring.

The scope of this paper included analyses of morphology, physicochemical properties and chemical composition of post-galvanized sewage sludge. In order to assess the risks arising from storing such type of waste, leaching and mobility analyses of selected metals in a wide range of $\mathrm{pH}$ were carried out in relation to the mass solubility of sewage sludge.

\section{Material and methods}

\section{Sample collection and preparation}

The object of the research was the postgalvanized sewage sludge from Koelner Screw Factory in Łańcut (Podkarpackie Voivodeship, SE Poland). The sewage sludge was dried at room temperature for 30 days until to get airdry state, and then it was triturated consecutively in ceramic and agate mortar $(\varphi \leq$ $100 \mu \mathrm{m})$. Thus prepared sludge was a laboratory sample, which was stored in a tightly closed bottle (PE) and used for research. Polyethylene bottles previously soaked in $10 \% \mathrm{HNO}_{3}$ by overnight and double washed by double distilled water.

\section{Reagents and instrumentation}

All chemicals and reagents were of analytical grade or higher purity and were obtained from POCH and CHEMPUR, Poland. The solutions were prepared by dissolving appropriate compounds in double-distilled water from the Water Purification System (SolPure 7 POLL LAB, Poland). Standard solutions were prepared from standard solutions for atomic absorption (Sigma-Aldrich Chemie $\mathrm{GmbH}$, Switzerland) - the concentrations of all metals in standard solutions were the same and equals $1.000 \mu \mathrm{g} \cdot \mathrm{cm}^{-3}$ in $1 \%$ of $\mathrm{HNO}_{3}$. Working standard solutions containing $\mathrm{Ca}, \mathrm{Cd}, \mathrm{Co}, \mathrm{Cr}$, $\mathrm{Cu}, \mathrm{Fe}, \mathrm{K}, \mathrm{Mg}, \mathrm{Mn}, \mathrm{Na}, \mathrm{Ni}, \mathrm{Pb}$ and $\mathrm{Zn}$ were prepared by serial dilution of the appropriately of standard solution for atomic absorption. Determination of the concentrations of metals in solutions has been performed by flame atomic absorption spectrometer PERKINELMER 3100 Model (Shelton Instruments, CT USA). The operating measurement conditions of the studied metals are summarized in Tab.1.

Tab.1. Optimal instrumental parameters for FAAS determination of metals (The Perkin-Elmer Corporation 1982)

\begin{tabular}{ccccccc}
\hline Metal & Wavelenght $[\mathrm{nm}]$ & $\begin{array}{c}\text { Spectral } \\
\text { width slit } \\
{[\mathrm{nm}]}\end{array}$ & $\begin{array}{c}\text { Time of } \\
\text { measurement }[\mathrm{s}]\end{array}$ & $\begin{array}{c}\text { Energy of lamp } \\
{[\mathrm{mA}]}\end{array}$ & $\begin{array}{c}\text { Concentration of } \\
\text { standard solutions } \\
{[\mathrm{ppm}]}\end{array}$ & $\begin{array}{c}\text { Sensivity } \\
{\left[\mathrm{mg} / \mathrm{dm}^{3}\right]}\end{array}$ \\
\hline $\mathrm{Ca}$ & 422.7 & 0.7 & 3 & 18 & $0-30$ & 0.092 \\
$\mathrm{Cd}$ & 228.8 & 0.7 & 3 & 6 & $0-12$ & 0.028 \\
$\mathrm{Co}$ & 241.2 & 0.2 & 3 & 38 & $0-3$ & 0.22 \\
$\mathrm{Cr}$ & 359.4 & 0.7 & 3 & 28 & $0-7$ & 0.10 \\
$\mathrm{Cu}$ & 324.8 & 0.7 & 3 & 22 & $0-5$ & 0.077 \\
$\mathrm{Fe}$ & 271.9 & 0.2 & 3 & 30 & $0-10$ & 0.34 \\
$\mathrm{~K}$ & 766.5 & 0.7 & 3 & 12 & $0-3$ & 0.043 \\
$\mathrm{Mg}$ & 285 & 0.7 & 3 & 28 & $0-12$ & 0.078 \\
$\mathrm{Mn}$ & 279.5 & 0.2 & 3 & 3 & $0-10$ & 0.052 \\
$\mathrm{Na}$ & 589 & 0.7 & 3 & 8 & $0-20$ & 0.012 \\
$\mathrm{Ni}$ & 341.5 & 0.2 & 3 & 18 & $0-6$ & 0.40 \\
$\mathrm{~Pb}$ & 217 & 0.7 & 3 & 3 & 38 & 0.19 \\
$\mathrm{Zn}$ & 213.9 & 0.7 & & 3 & & 0.018 \\
\hline
\end{tabular}


Physicochemical characteristics of postgalvanized sewage sludge

The physicochemical properties of sewage sludge were marked in according the standard procedures used to characteristics of sewage sludge, force in Poland. Determination of moisture content in sludge was performed by using the moisture analyzer (model MAX50/1, Radwag, Poland). Measurements were conducted with a stepped profile at temperatures $40^{\circ} \mathrm{C}, 60^{\circ} \mathrm{C}$ and $98^{\circ} \mathrm{C}$. Loss on ignition (LOI) was determined using a muffle furnace (model FCF 12SM, Czylok, Poland), at temperature $900^{\circ} \mathrm{C}$. Roasting was carried out for two hours to a constant weight. The bulk density was determined in uncompressed and thickened state. Markings of $\mathrm{pH}$ sludge were carried out in distilled water $(\mathrm{pH}=7)$ and neutral salt solutions: $1 \mathrm{M} \mathrm{KCl}$ and $0.01 \mathrm{M}$ $\mathrm{CaCl}_{2}$. The $\mathrm{pH}$ measurement was performed using a $\mathrm{pH}$ meter (model CP-501, Elmetron, Poland), equipped with a glass electrode (Eurosensor, Poland), after prior calibration. Analyses were performed in triplicate, the results presented are an arithmetic average of the three tests with a confidence interval designated with $\mathrm{t}-$ Student distribution for $\mathrm{p}=$ $95 \%$.

Chemical composition of post-galvanized sewage sludge

The total content of metals $(\mathrm{Ca}, \mathrm{Cd}, \mathrm{Co}, \mathrm{Cr}$, $\mathrm{Cu}, \mathrm{Fe}, \mathrm{K}, \mathrm{Mg}, \mathrm{Mn}, \mathrm{Na}, \mathrm{Ni}, \mathrm{Pb}, \mathrm{Zn}$ ) were analyzed by one-step mineralization of sludge in a mixture of concentrated acid by procedure: 1.0000 g sludge $(\varphi \leq 100 \mu \mathrm{m})$ was digested with a mixture of concentrated acid $\left(10 \mathrm{~cm}^{3}\right.$ $\mathrm{HClO}_{4}, 10 \mathrm{~cm}^{3} \mathrm{HF}, 5 \mathrm{~cm}^{3} \mathrm{H}_{2} \mathrm{O}$ ). The digestion was carried out in crucibles of PTFE $\AA$ at room temperature for 16 hours. After this time, the crucible contents was heated on a hot plate (HP model 88720-26 Barnstead / Thermolyne, USA) at $50-60{ }^{\circ} \mathrm{C}$ and then evaporated to dryness. To the dry residue was added again $10 \mathrm{~cm}^{3} \mathrm{HClO}_{4}, 10 \mathrm{~cm}^{3} \mathrm{HF}, 5 \mathrm{~cm}^{3} \mathrm{H}_{2} \mathrm{O}$ and again evaporated to dryness. At the end of $5 \mathrm{~cm}^{3}$ of $\mathrm{HClO}_{4}$ was added and again evaporated to dryness. To the residue was added $5 \mathrm{~cm}^{3}$ of $\mathrm{HNO}_{3}$ and $25 \mathrm{~cm}^{3} \mathrm{H}_{2} \mathrm{O}$, then the resulting solution was quantitatively transferred to a volumetric flask and supplemented with distilled water to a specified volume. The metal content $(\mathrm{Ca}, \mathrm{Cd}, \mathrm{Co}, \mathrm{Cr}, \mathrm{Cu}, \mathrm{Fe}, \mathrm{K}, \mathrm{Mg}$, $\mathrm{Mn}, \mathrm{Na}, \mathrm{Ni}, \mathrm{Pb}, \mathrm{Zn}$ ) in the obtained solution determined by method FAAS. Simultaneously the reagent blank was prepared by introducing into the crucible of PTFE® the same amounts reagents and taking the same steps as when preparing samples of sewage sludge.

The contents of nonmetals $(\mathrm{C}, \mathrm{H}, \mathrm{N}, \mathrm{S})$ in the sludge was determined by direct elemental analyses using an elemental analyzer (model Vario EL III Elementar, Germany).

\section{Scanning electron microscope (SEM)}

The morphology of the sewage sludge were carried out with scanning electron microscope (S-3400N, Hitachi), which allows observation of the surface of materials with enlargement of $5 \mathrm{x}$ to $100000 \mathrm{x}$, equipped with an adapter for chemical analysis of microsites (EDS). Preparations were made by placing the sample on the carbon tape without sputtering.

Leachability of metals from post-galvanized sewage sludge

The samples of the sludge weight of $5.0000 \mathrm{~g}$ were leaching by solutions $\left(\mathrm{HNO}_{3}, \mathrm{KOH}\right)$ at $\mathrm{pH}$ range of 1 - 10. Experimentation was performed at room temperature for 24 hours, mixing periodically. The eluates were separated from the solid residue by centrifugation $(\mathrm{t}=5$ minutes, $\mathrm{r}=3000 \mathrm{rpm})$ and then filtered to volumetric flask, adding to each sample of $1 \mathrm{~cm}^{3}$ of $1 \mathrm{M} \mathrm{HNO}_{3}$ and complementing with distilled water to a 
constant volume $\left(50 \mathrm{~cm}^{3}\right)$. In the resulting solution the concentrations of $\mathrm{Co}, \mathrm{Fe}, \mathrm{Ni}, \mathrm{Pb}$ and $\mathrm{Zn}$ were determined by FAAS technique. The solid residue was dried in a laboratory drier to a constant weight and weighed, based on this mass solubility of sludge was calculated in the $\mathrm{pH}$ range of 1-10.

\section{Results and discussion}

Post-galvanized sewage sludge has a dark green rusty color when is moist and a pale yellow rusty color when is dry. The sewage sludge samples have hygroscopic properties causing their grains to stick together forming particle aggregates. Water content of tested material is very high and amounts to $74.44 \%$ $( \pm 0.64)$. LOI determined at $900^{\circ} \mathrm{C}$ amounts to $34.63 \%( \pm 0.07)$, so large LOI value is one of the parameters which exclude the possibility of waste storage in accordance the Regulation of the Minister of Economy of 8 January 2013. The size of sewage sludge individual grains, morphology and the size and number of pores between them determine the value of sewage sludge bulk density. The bulk density of analyzed sewage sludge in an uncompressed state amounts to $0.584 \mathrm{~g} / \mathrm{cm}^{3}( \pm 0.002)$ and in thickened state to $0.825 \mathrm{~g} / \mathrm{cm}^{3}$ ( \pm 0.004$)$. The $\mathrm{pH}$ value of sewage sludge varies widely and depends on the production processes in which the sludge was produced (Środa et al. 2012). The analyzed sewage sludge in all analyzed solutions is characterized by alkaline $\mathrm{pH}(8.30$ - $\mathrm{H}_{2} \mathrm{O} ; 8.33-0.1 \mathrm{M} \mathrm{KCl} ; 8.26-0.01 \mathrm{M}$ $\mathrm{CaCl}_{2}$ ). The content of analyzed elements in sewage sludge both metals $(\mathrm{Cu}, \mathrm{Cd}, \mathrm{Co}, \mathrm{Cr}$, $\mathrm{Cu}, \mathrm{Fe}, \mathrm{K}, \mathrm{Mg}, \mathrm{Mn}, \mathrm{Na}, \mathrm{Ni}, \mathrm{Pb}, \mathrm{Zn}$ ) and nonmetals (C, H, N, S) is diverse (Fig. 1). The largest concentration among metals was observed in the case of calcium (33.9\%), zinc (25.3\%) and iron (12.1\%). High content of Ca, $\mathrm{Zn}$ and $\mathrm{Fe}$ is related to production processes carried out during pickling, galvanizing and neutralization during wastewater treatment. The contents of $\mathrm{Co}, \mathrm{Cr}, \mathrm{Cu}, \mathrm{K}, \mathrm{Mn}, \mathrm{Ni}$ and $\mathrm{Pb}$ in the sewage sludge are below $1 \%$ whereas the concentration of $\mathrm{Cd}$ is below the limit of quantification within FAAS method. The contents of analyzed non-metals are as follows: coal $-10.03 \%$, hydrogen $-1.12 \%$, nitrogen $0.17 \%$, sulfur $-0.26 \%$.

According to the data presented by KabataPendias (2011) the typical content of heavy metals in sewage sludge ( $\mathrm{mg}$ of metal $/ \mathrm{kg}$ of sewage sludge) is as follows: $\mathrm{Cd}(2-1500), \mathrm{Cr}$ (20 - 40600), Co ( 2 - 260), Mn (60 - 9300), Cu (50 - 3300), Ni (16 - 5300), Pb (33 - 3000), Zn (550 - 4900). Comparing the data obtained by determining the samples after a complete mineralization with the literature data it can be noticed that the determined concentrations for $\mathrm{Cr}, \mathrm{Cu}, \mathrm{Mn}, \mathrm{Ni}$ and $\mathrm{Pb}$ are included in the fixed scale of concentrations, and the upper limit of content in the case of cobalt and zinc was exceeded respectively 20 times and 5 times.

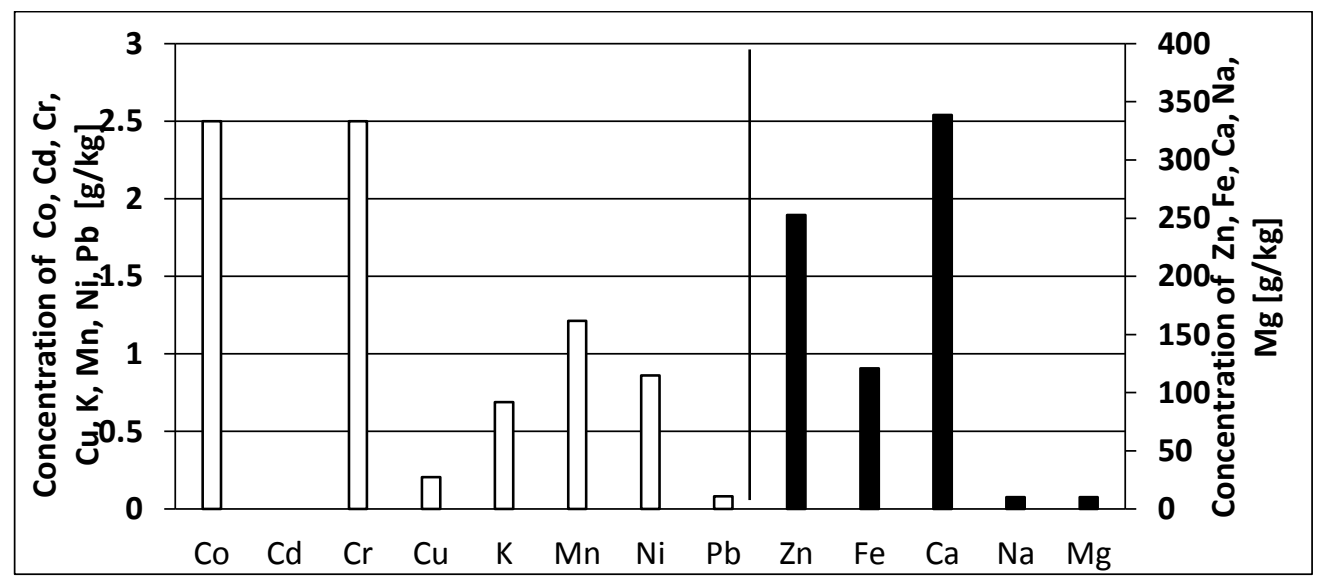

Fig.1. Selected metals concentrations in post-galvanized sewage sludge. 
Short-term and long-term storage of sewage sludge characterized by a high content of analyzed metals poses a high risk of penetration of these metals into soil and groundwater.

SEM images (Fig. 2) indicate that the morphology of analyzed material is complex. A predominant number of particles of irregular shapes were noticed. The sizes of individual grains are ranging from less than $10 \mu \mathrm{m}$ to over $300 \mu \mathrm{m}$. The finest grains appear in forms of aggregates which are binding larger particles.

$\mathrm{X}$-ray microanalysis enables identification of elements in selected area under a scanning microscope and their arrangement along a specified line (Kutcho and Kim 2006). The carried out EDS analyses indicate presence of oxygen, silicon, calcium, chromium, iron and zinc in all tested areas (Fig. 3). Presence of magnesium was detected in area 1 and 2, whereas presence of copper in area 3. The sewage sludge samples are characterized by highly changeable chemical composition. The spread of chemical composition of grains is significant. Single grains of sewage sludge can be built from a small number of compounds or can represent only one component. Detailed data on X-ray microanalysis has been shown in Tab.2.

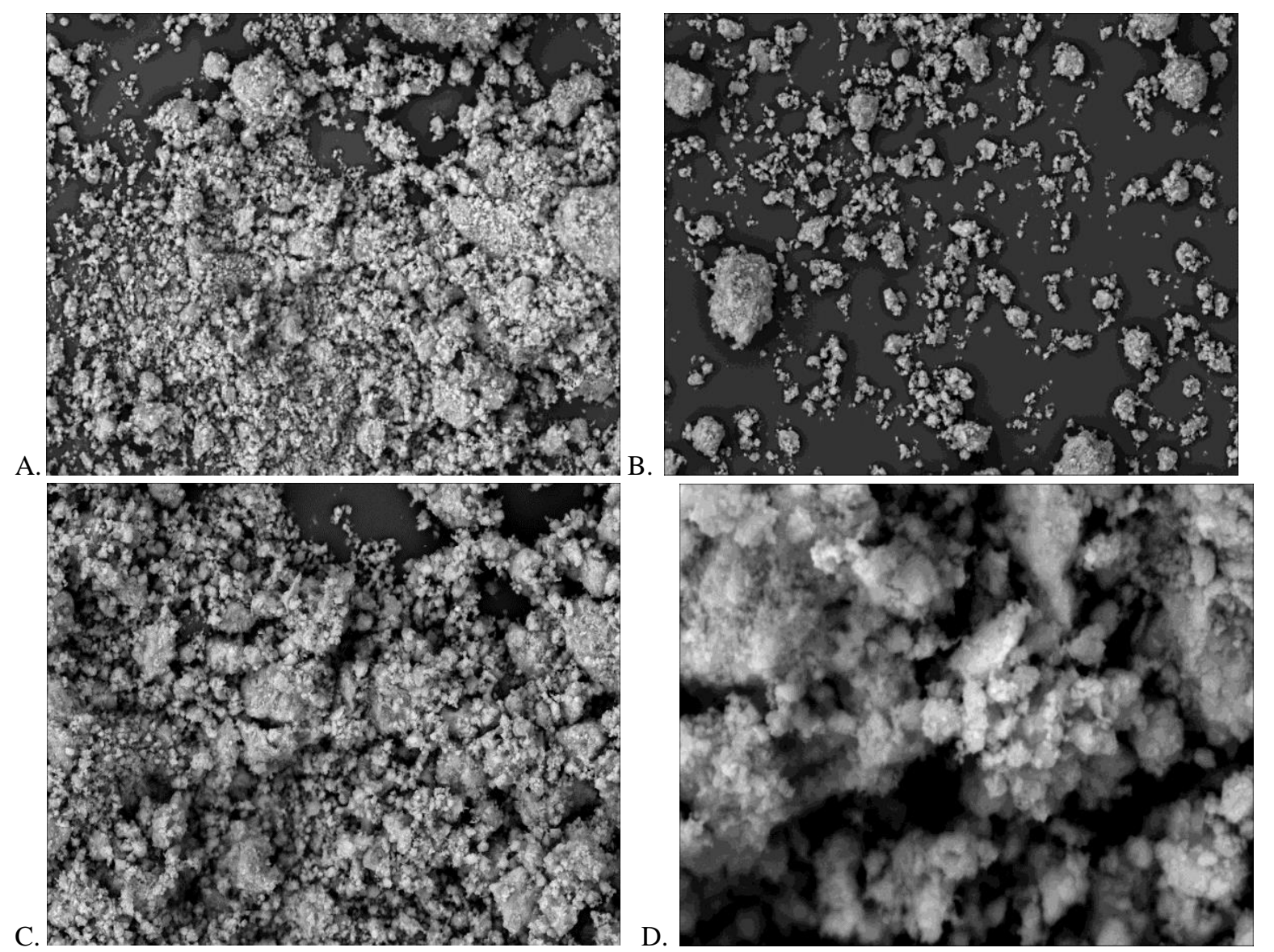

Fig.2. The SEM images of post-galvanized sewage sludge at the different magnifications: $100 \mu \mathrm{m}$ (A and B), 50 $\mu \mathrm{m}(\mathrm{C}), 10 \mu \mathrm{m}(\mathrm{D})$.

Tab.2. Content of metals (\%) in sewage sludge *(symbol element - symbol elektron shell)

\begin{tabular}{ccccccccr}
\hline Areas of study & \multicolumn{1}{c}{$\mathrm{O}-\mathrm{K}^{*}$} & \multicolumn{1}{c}{$\mathrm{Mg}-\mathrm{K}$} & \multicolumn{1}{c}{$\mathrm{Si}-\mathrm{K}$} & $\mathrm{Ca}-\mathrm{K}$ & $\mathrm{Cr}-\mathrm{K}$ & $\mathrm{Fe}-\mathrm{K}$ & $\mathrm{Cu}-\mathrm{K}$ & $\mathrm{Zn}-\mathrm{K}$ \\
\hline Area 1 & 31.1 & 0.8 & 3.9 & 4.4 & 1.0 & 26.1 & - & 32.8 \\
Area 2 & 18.6 & 1.0 & 5.0 & 5.6 & 1.1 & 28.6 & - & 40.1 \\
Area 3 & 14.2 & - & 3.0 & 12.8 & 1.7 & 29.2 & 1.7 & 37.5 \\
\hline
\end{tabular}




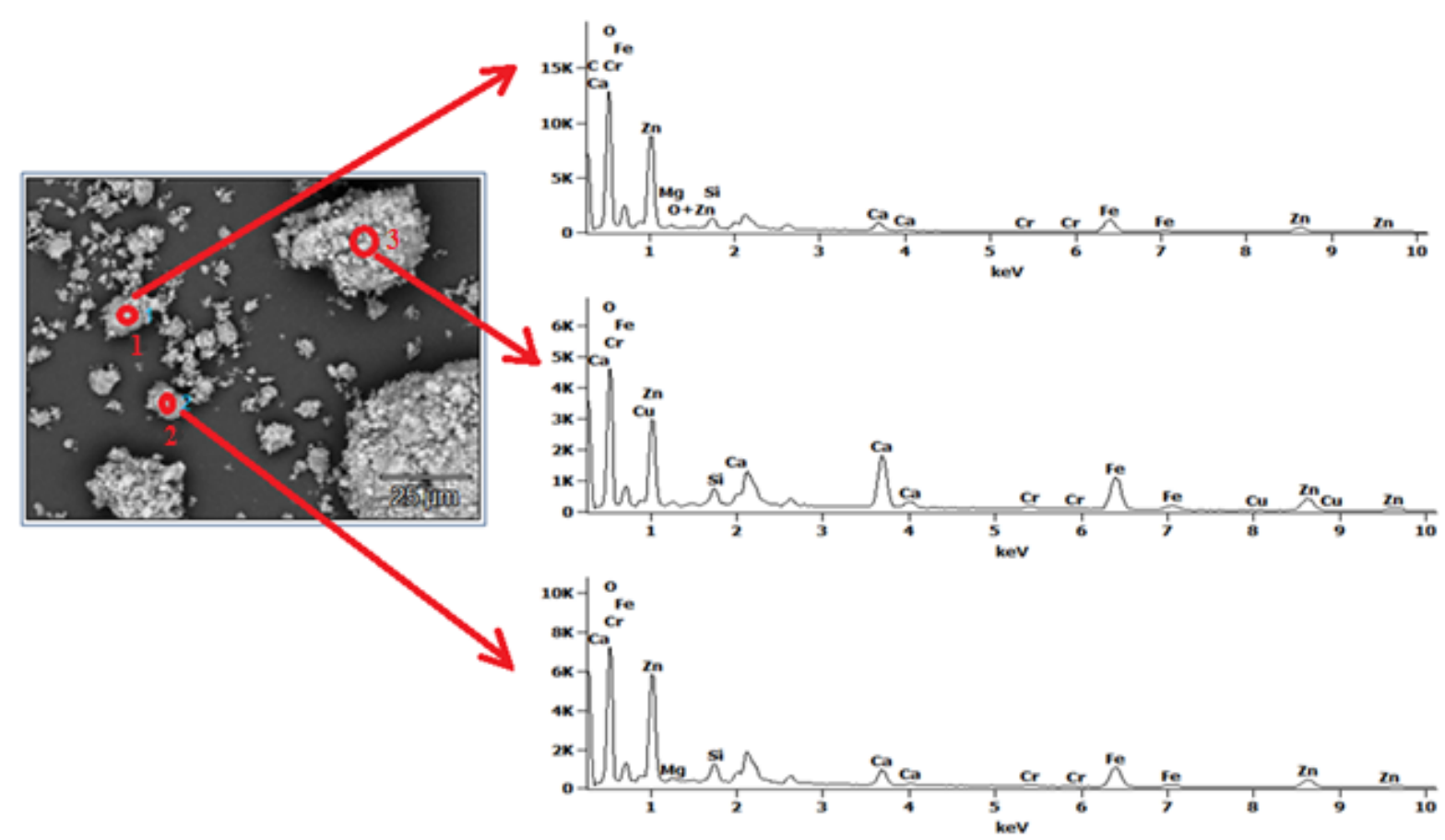

Fig.3. EDS spectra for sewage sludge (1, 2, 3 - areas of study)

Analyses of mass solubility of sewage sludge indicate a significant effect of the environmental reaction on mass loss of analyzed samples. The highest value was observed at $\mathrm{pH}=1(7.2 \%)$, whereas at $\mathrm{pH}$ between 2 and 10 the mass solubility amounts from $2.8 \%$ to $4.2 \%$ (Tab.3).

Significant effect of environmental reaction $(\mathrm{pH} 1-10)$ on leaching of metals and their mobility was recorded in the sewage sludge - solution system. The highest content of leachable forms of $\mathrm{Co}, \mathrm{Fe}, \mathrm{Mn}, \mathrm{Ni}$ and $\mathrm{Zn}$ occurred in acidic medium $(\mathrm{pH}=1)$. At $\mathrm{pH}$ range of 3-10 the content of $\mathrm{Co}, \mathrm{Mn}, \mathrm{Ni}$ and $\mathrm{Fe}$ is below the limit of detection within FAAS method. Concentration of zinc at $\mathrm{pH}$ between 3 and 10 varies from 1.00 to $4.66 \mathrm{mg} / \mathrm{kg}$ (Tab.4). Extraction with neutral aqueous solution releases the most mobile and available forms of metals. Increasing the degree of leaching solution acidity results in dissolution of metal forms connected to acids and also increases the degree of sewage sludge solubility.

The accumulation coefficient of mobile fraction connected with mass solubility of sewage sludge measures the degree of leaching process of metals from sludge. The accumulation coefficient of mobile metals fraction allows to specify which part of metal contains soluble fraction of material. The accumulation coefficient is calculated according to the following formula (1):

$$
A=\frac{m_{M}}{\Delta m}
$$

where:

A - accumulation coefficient of mobile metal fractions

$\mathrm{m}_{\mathrm{M}}$ - mass of mobile metal $(\mathrm{g})$ in waste for a certain $\mathrm{pH}$

$\Delta \mathrm{m}$-mass loss $(\mathrm{g})$ of sewage sludge for a certain $\mathrm{pH}$

The maximum values of accumulation coefficients of mobile fractions were recorded in acidic medium. The accumulation coefficients of mobile metals fractions at $\mathrm{pH}=$ 1 have values ranging from $9.7 \cdot 10^{-5}(\mathrm{Fe})$ to $5 \cdot 10^{-2}(\mathrm{Zn})$, and due to the increase of their values they form the following: $\mathbf{A}(\mathrm{Fe})<$ $\mathbf{A}(\mathrm{Ni})<\mathbf{A}(\mathrm{Mn})<\mathbf{A}(\mathrm{Co})<\mathbf{A}(\mathrm{Zn})$. For zinc in the range of $\mathrm{pH}$ 3-10 the accumulation coefficient of mobile fraction is ranging from $2.4 \cdot 10^{-5}$ to $1.9 \cdot 10^{-4}$. Tab.5 presents accumulation coefficients of mobile fractions of tested metals in sewage sludge in the range of $\mathrm{pH} 1-10$. 
Tab.3. The mass solubility of analyzed sewage sludge in the range of $\mathrm{pH} 1-10(\mathrm{n}=3, \mathrm{p}=95 \%)$

\begin{tabular}{ccccccccccc}
\hline $\mathrm{pH}$ & 1 & 2 & 3 & 4 & 5 & 6 & 7 & 8 & 9 & 10 \\
\hline Weight & 7.21 & 2.84 & 2.69 & 3.76 & 3.99 & 4.20 & 3.05 & 3.10 & 3.01 & 3.10 \\
loss [\%] & \pm 0.35 & \pm 0.06 & \pm 0.48 & \pm 0.90 & \pm 0.35 & \pm 0.38 & \pm 0.57 & \pm 0.34 & \pm 0.35 & \pm 0.39 \\
\hline
\end{tabular}

Tab.4. The content of mobile $\mathrm{Mn}, \mathrm{Co}, \mathrm{Ni}, \mathrm{Fe}$ and $\mathrm{Zn}$ in the sewage sludge (d. 1. - detection limit)

\begin{tabular}{|c|c|c|c|c|c|c|c|c|c|c|}
\hline \multicolumn{11}{|c|}{ The content of $\mathrm{Mn}, \mathrm{Co}, \mathrm{Ni}, \mathrm{Zn}$ oraz $\mathrm{Fe}(\mathrm{mg} / \mathrm{kg})$ in the range of $\mathrm{pH} 1-10$} \\
\hline $\mathrm{pH}$ & 1 & 2 & 3 & 4 & 5 & 6 & 7 & 8 & 9 & 10 \\
\hline Mn & $\begin{array}{r}110.2 \\
\pm 6.55\end{array}$ & $\begin{array}{c}4.66 \\
\pm 0.58\end{array}$ & $<\mathrm{d} .1$. & $<\mathrm{d} .1$. & $<\mathrm{d} .1$. & $<\mathrm{d} .1$. & $<\mathrm{d} .1$. & $<\mathrm{d} .1$. & $<\mathrm{d} .1$. & $<$ d. 1. \\
\hline $\mathrm{Co}$ & $\begin{array}{l}96.57 \\
\pm 4.7\end{array}$ & $\begin{array}{c}1.00 \\
\pm 0.01\end{array}$ & $<\mathrm{d} .1$. & $<\mathrm{d} .1$. & $<\mathrm{d} .1$ & $<\mathrm{d} .1$ & $<$ d. 1. & $<\mathrm{d} .1$. & $<\mathrm{d} .1$ & $<$ d. 1. \\
\hline $\mathrm{Ni}$ & $\begin{array}{l}22.65 \\
\pm 1.2\end{array}$ & $\begin{array}{c}1.33 \\
\pm 0.01\end{array}$ & $<\mathrm{d} .1$. & $<$ d. 1. & $<\mathrm{d} .1$. & $<\mathrm{d} .1$. & $<\mathrm{d} .1$. & $<\mathrm{d} .1$. & $<$ d. 1. & $<\mathrm{d} .1$. \\
\hline $\mathrm{Zn}$ & $\begin{array}{l}3580.0 \\
\pm 14.6\end{array}$ & $\begin{array}{c}33.31 \\
\pm 1.55\end{array}$ & $\begin{array}{c}4.66 \\
\pm 0.55\end{array}$ & $\begin{array}{c}2.00 \\
\pm 0.05\end{array}$ & $\begin{array}{c}2.00 \\
\pm 0.10\end{array}$ & $\begin{array}{c}1.00 \\
\pm 0.01\end{array}$ & $\begin{array}{c}2.66 \\
\pm 0.20\end{array}$ & $\begin{array}{c}2.66 \\
\pm 0.15\end{array}$ & $\begin{array}{c}3.66 \\
\pm 0.45\end{array}$ & $\begin{array}{c}2.00 \\
\pm 0.05\end{array}$ \\
\hline $\mathrm{Fe}$ & $\begin{array}{c}6.66 \\
\pm 0.50\end{array}$ & $<\mathrm{d} .1$. & $<\mathrm{d} .1$. & $<\mathrm{d} .1$. & $<\mathrm{d} .1$. & $<\mathrm{d} .1$. & $<\mathrm{d} .1$. & $<\mathrm{d} .1$. & $<\mathrm{d} .1$. & $<$ d. 1. \\
\hline
\end{tabular}

Tab.5. Accumulation coefficient of mobile fractions $\mathrm{Mn}, \mathrm{Co}, \mathrm{Ni}, \mathrm{Zn}$ and $\mathrm{Fe}$ in the range $\mathrm{pH} 1-10$

\begin{tabular}{cccccc}
\hline \multirow{2}{*}{$\mathrm{pH}$} & \multicolumn{5}{c}{ Accumulation coefficient of mobile fractions } \\
\cline { 2 - 6 } & $\mathrm{A}(\mathrm{Mn})$ & $\mathrm{A}(\mathrm{Co})$ & $\mathrm{A}(\mathrm{Ni})$ & $\mathrm{A}(\mathrm{Zn})$ & $\mathrm{A}(\mathrm{Fe})$ \\
\hline 1 & $1.5 \cdot 10^{-3}$ & $1.3 \cdot 10^{-3}$ & $3.2 \cdot 10^{-4}$ & $5.0 \cdot 10^{-2}$ & $9.7 \cdot 10^{-5}$ \\
2 & $1.8 \cdot 10^{-4}$ & $1.5 \cdot 10^{-5}$ & $3.5 \cdot 10^{-5}$ & $1.2 \cdot 10^{-3}$ & - \\
3 & - & - & - & $1.9 \cdot 10^{-4}$ & - \\
4 & - & - & - & $5.3 \cdot 10^{-5}$ & - \\
5 & - & - & - & $5.0 \cdot 10^{-5}$ & - \\
6 & - & - & - & $2.4 \cdot 10^{-5}$ & - \\
7 & - & - & - & $9.8 \cdot 10^{-5}$ & - \\
8 & - & - & - & $9.7 \cdot 10^{-5}$ & - \\
9 & - & - & - & $1.3 \cdot 10^{-4}$ & - \\
10 & - & - & - & $6.5 \cdot 10^{-5}$ & - \\
\hline
\end{tabular}

In order to assess the risk arising from the storage of post-galvanized sewage sludge, leaching levels of analyzed metals were calculated in accordance with $\mathrm{pH}$ of leaching solution and the following formula (2) (Mizerna and Król 2015):

$$
\text { Leaching level }=\frac{\mathrm{C}_{\text {eluate }}}{\mathrm{C}_{\text {sludge }}} \cdot 100 \%
$$

where:

$\mathrm{c}_{\text {eluate }}$ - concentration of mobile metal $(\mathrm{mg} / \mathrm{kg})$ for a certain $\mathrm{pH}$,

$\mathrm{c}_{\text {sludge }}$ - the total content of metal $(\mathrm{mg} / \mathrm{kg})$ in sewage sludge.

The highest values of leaching levels were recorded in acidic medium $(\mathrm{pH}=1)$ from $0,006 \%(\mathrm{Fe})$ to $9.12 \%(\mathrm{Mn})$ (Tab.6). Leaching of $\mathrm{Ni}$ and $\mathrm{Zn}$ is one of the parameters defining possibility of waste storage in dedicated landfills (hazardous, inert waste or other). The results obtained regarding leaching of $\mathrm{Ni}$ and $\mathrm{Zn}$ were compared with the boundary values set out in the Regulation of the Minister of Economy of 8 January 2013 on the criteria and procedures of accepting waste storage in dedicated landfill. In the case of nickel, the acceptable leaching value for hazardous waste landfills and all extractants was not exceeded. In the case of zinc, with the use of the leaching solution of $\mathrm{pH}=1$, the recorded value exceeded approx. 18 times the acceptable leaching level regarding hazardous waste landfills. Such a high content of zinc in postgalvanized sewage sludge indicates that it should be removed before storage or a method of its recycling should be developed. 
Tab.6. Leaching level of $\mathrm{Mn}, \mathrm{Co}, \mathrm{Ni}, \mathrm{Zn}$ and $\mathrm{Fe}$ from post-galvanized sewage sludge in the range $\mathrm{pH}$ 1-10

\begin{tabular}{|c|c|c|c|c|c|}
\hline \multirow{2}{*}{$\mathrm{pH}$} & \multicolumn{5}{|c|}{ Leaching level $\mathrm{Mn}, \mathrm{Co}, \mathrm{Ni}, \mathrm{Zn}$ and $\mathrm{Fe}$} \\
\hline & $\mathrm{Mn}$ & $\mathrm{Co}$ & $\mathrm{Ni}$ & $\mathrm{Zn}$ & $\mathrm{Fe}$ \\
\hline 1 & $9.12 \%$ & $3.86 \%$ & $2.63 \%$ & $1.42 \%$ & $0.01 \%$ \\
\hline 2 & $0.39 \%$ & $0.04 \%$ & $0.15 \%$ & $0.013 \%$ & - \\
\hline 3 & - & - & - & $0.002 \%$ & - \\
\hline 4 & - & - & - & $0.001 \%$ & - \\
\hline 5 & - & - & - & $0.001 \%$ & - \\
\hline 6 & - & - & - & $0.0004 \%$ & - \\
\hline 7 & - & - & - & $0.001 \%$ & - \\
\hline 8 & - & - & - & $0.001 \%$ & - \\
\hline 9 & - & - & - & $0.001 \%$ & - \\
\hline 10 & - & - & - & $0.001 \%$ & - \\
\hline
\end{tabular}

\section{Summary}

1. The following physicochemical parameters of sewage sludge from Koelner Screw Factory in Łańcut, Poland has been determined: moisture content (74.44\%), loss on ignition (34.63\%), pH (in $\mathrm{H}_{2} \mathrm{O}$ 8.30, in $\mathrm{KCl}-8.33$, in $\mathrm{CaCl}_{2}-8.26$ ), bulk density in an uncompressed state $(0.58$ $\left.\mathrm{g} / \mathrm{cm}^{3}\right)$ and thickened state $\left(0.83 \mathrm{~g} / \mathrm{cm}^{3}\right)$.

2. Analyses of the total metal content show that predominant share in waste has calcium (33.8\%) and zinc (25.3\%). Such a large amount of calcium and zinc is probably connected with two production processes (pickling and galvanizing) carried out in Screw Factory in Łańcut.

3. Analyses of the solubility of sewage sludge mass highlight the significant effect of environment reaction on mass loss of analyzed samples. The highest value was recorded at $\mathrm{pH}=1(7.2 \%)$.

4. Environmental reaction ( $\mathrm{pH} 1-10)$ has a significant effect on leaching of metals and their mobility in the industrial waste solution system. The maximum values of accumulation coefficients of mobile metals fractions were recorded in acidic medium (from $9.7 \cdot 10^{-5}$ for Fe to $5 \cdot 10^{-2}$ for $\mathrm{Zn}$ ). The highest levels of leaching of tested metals were also recorded in acidic medium (from $0.006 \%$ for Fe to $9.12 \%$ for $\mathrm{Mn}$ ).

\section{Acknowledgments}

Authors would like to thank Dr Eng M. Wierzbińska from Department of Materials Science, Rzeszow University of Technology for doing research SEM/EDS.

\section{References}

Bojanowska I., Śniegocka A., Ormińska M., Dembińska K. (2001) Treatment of Wastewater and the Solid Waste Management from the Chemical Surface Treatment (Oczyszczanie ścieków i zagospodarowanie odpadów stałych pochodzących z chemicznej obróbki powierzchni metali). Chemia i Inżynieria Ekologiczna 8: 279-287.

Central Statistical Office (2015) Statistical Yearbook of Industry - Poland. Statistical Publishing Establishment, Warsaw.

Duffus J. (2002) „Heavy metals” a meaningless term? (IUPAC Technical Report). Pure Applied Chemistry 74: $793-$ 807, doi: 10.1351/pac200274050793.

Duruibe J.O., Ogwuegbu M.O.C., Egwurugwu, J.N. (2007) Heavy metal pollution and human biotoxic effects, International Journal of Physical Sciences 2, 5: 112-118.

Espinosa D.C.R., Tenório J.A.S. (2001) Thermal behavior of chromium electroplating sludge. Waste Management 21, 4: 405-410, doi:10.1016/S0956053X(00)00056-8. 
Grabas K. (2009) Removal of Heavy Metal Ions from an Electroplating Effluent and the Clarified Water of the "Kowary" Tailing Pond (Jelenia Gora District, Lower Silesia) (Usuwanie jonów metali ciężkich ze ścieków przemysłowych i wód nadosadowych ze stawu „Kowary” (powiat jeleniogórski)). Ochrona Środowiska 31: 49-54.

Haoxin L., Xiaojie Y., Wei X., Jianguo W., Jingcheng X., Guofang Z., Yibing X. (2014) Application of dry composite electroplating sludge into preparation of cement-based decorative mortar as green pigment. Journal of Cleaner Production 66: 101-106.

Kabata-Pendias A. (2011) Trace Elements in Soils and Plants. CRC PressTaylor \& Francis Group.

Kutcho B., Kim A. (2006) Fly ash characterization by SEM-EDS. Fuel 85, 17-18: 2537-2544, doi: 10.1016/j.fuel.2006.05.016.

Lambolez L., Vasseur P., Ferard J.F., Gisbert T. (1994) The environmental risks of industrial waste disposal: an experimental approach including acute and chronic toxicity studies. Ecotoxicology and Environmental Safety 28, 3: 317-328, doi:10.1006/eesa.1994.1056.

Mizerna K., Król A. (2015) The influence of selected factors on the leaching of heavy metals from smelter wast. Ecological Engineering 43: 1-6, doi: 10.12912/23920629/58898.

Rosolak M., Gworek B. (2006) State and assessment of waste management in Poland (Stan i ocena gospodarki odpadami w Polsce). Ochrona Środowiska i Zasobów Naturalnych 29: 71-84.

Regulation of the Minister of Economy of 8 January 2013 on the criteria and procedures for the release of waste to the landfill type (Rozporządzenie Ministra Gospodarki z dnia 8 stycznia 2013 r. w sprawie kryteriów oraz procedur dopuszczania odpadów do składowania na składowisku odpadów danego typu).

Rubel E., Tomassi T., Ziółkowski J. (2009) The best available techniques (BAT). Guidelines for the surface treatment of metals and plastics. Update January 2000. Instytut Mechaniki Precyzyjnej, Warszawa.

Ruth H., Kuo-Lin H., Zih-Yi L., Jian-Wen W., Chitsan L., Yi-Ming K. (2013) Recovery of valuable metals from electroplating sludge with reducing additives via vitrification. Journal of Environmental Management 129: 586-592, doi:10.1016/j.jenvman.2013.08.019.

Surgiewicz J., Domański W. (2006) (The exposure to metal compounds in industrial processes galvanic) Narażenie na związki metali w przemysłowych procesach galwanicznych. Medycyna Pracy 57, 2: 123-131.

Środa K., Kijo-Kleczkowska A., Otwinowski H. (2012) Thermal disposal of sewage sludge (Termiczne unieszkodliwianie osadów ściekowych). Inżynieria Ekologiczna 28: 67-81.

The Perkin-Elmer Corporation (1982) Analytical Methods for Atomic Absorption Spectrophotometry. Norwalk Connecticut, USA.

Wengierek M. (2014) Recovery and recycling as a methods of waste management in the region (Odzysk i recykling jako metody zagospodarowania odpadów w regionie). Zeszyty Naukowe Politechniki Śląskiej 70: 477-490. 